Article

\title{
Community-Supported Agriculture as a Perspective Model for the Development of Small Agricultural Holding in the Region
}

\author{
Mirosław Struś ${ }^{1}\left(\right.$, Magdalena Kalisiak-Mędelska ${ }^{2}$, , Michał Nadolny $^{3}$, Marian Kachniarz ${ }^{4}(\mathbb{D}$ \\ and Magdalena Raftowicz ${ }^{2, *(D)}$ \\ 1 Institute of Economics Sciences, Faculty of Law, Administration and Economics, University of Wrocław, \\ 50-137 Wrocław, Poland; miroslaw.strus@uwr.edu.pl \\ 2 Institute of Economics Sciences, Faculty of Life Sciences and Technology, Wroclaw University of \\ Environmental and Life Sciences, 50-375 Wroclaw, Poland; magdalena.kalisiak-medelska@upwr.edu.pl \\ 3 Management Institute, Wroclaw University of Economics and Business, 53-345 Wrocław, Poland; \\ Michal.Nadolny@ue.wroc.pl \\ 4 Department of Spatial Economy, Wroclaw University of Environmental and Life Sciences, \\ 50-375 Wrocław, Poland; marian.kachniarz@upwr.edu.pl \\ * Correspondence: magdalena.raftowicz@upwr.edu.pl
}

Received: 3 February 2020; Accepted: 23 March 2020; Published: 27 March 2020

\begin{abstract}
Globalization and the related processes of land and capital concentration are also present in Polish agriculture. As a result of the occurring changes in agriculture itself and in its environment, the importance of small agricultural holdings is permanently declining. The gradual disappearance of small family farms not only disrupts the direct relationships between food producers and consumers, but also puts food security at risk, primarily on a local and regional scale. The purpose of the article is an attempt to present that the development of Community-Supported Agriculture (CSA) can offer an alternative to the occurring current distribution channels. The article is focused on the possibilities of CSA development in the Wrocław district resulting from the proximity of the largest market in the Lower Silesia region-Wrocław (the capital of Lower Silesia in Poland). The survey covered 400 agricultural holdings located in nine municipalities of the Wrocław district. The conducted research has shown that the CSA model opens opportunities for a long-lasting cooperation between farmers and consumers, but its implementation requires an increase in the prices of agricultural products offered by farmers by about $50 \%$, as well as solutions to the cost-related problems of agricultural product transport.
\end{abstract}

Keywords: community supported agriculture; small agricultural holdings; development model; Wrocław district

\section{Introduction}

As a result of socio-economic changes occurring in Polish agriculture, there is an ongoing discussion about the economic role of rural areas and the directions for their evolvement. Area changes, intensified competition, and market presence of major retail chains expecting large deliveries of goods presenting standard features, on the one hand, force the necessary modernization of rural areas; on the other hand, they deprive them considerably of their actual tradition. It is mistakenly believed that the development processes in these areas should be carried out analogously to those observed, e.g., in large cities, representing the leading growth centers [1]. Nevertheless, it was the intensive development of cities that brought about an increased demand for agricultural products, which resulted in the 
growing importance of trade and processing of agricultural products [2], whereas that did not remain indifferent to the organization and nature of agricultural holdings.

Undeniably, the pressure to "speed up development" placed small agricultural holdings in a difficult situation. Their location is additionally hindered by an increasingly intense concentration of land, supported by the economic advantages of large-area farms meeting the sustainability criteria to a greater extent [3]. It should be remembered that the land, as the key production factor, determines the type of agriculture, the farming method used, and, in consequence, its efficiency and competitiveness [4].

Contrary to the neoliberal approach to globalization and new technologies, that "a rising tide raises all boats" $[5,6]$, these trends have contributed to a significant deterioration of the situation and, consequently, the importance of small agricultural holdings. Global corporations operating in the sector of agri-food processing and trade prefer cooperation with large agricultural holdings because of their capacity regarding delivery size, keeping the deadlines, or lower transaction costs. Moreover, capital-intensive technologies or biotechnological progress are mainly implemented on large agricultural holdings [7]. This is predominantly due to the fact that in the case of small farms, the absorption of modernization and innovation investments is carried out much more slowly and with lower intensity [8].

The aforementioned circumstances have significantly reduced the competitiveness of small agricultural holdings and, thus, the level of generated income. Moreover, the relationship stability between farmers and consumers has been violated, thus exposing farmers to the dangers of cyclical fluctuations. As a result, the atrophy of traditional family farms (up to 10 ha) has been observed, in the long run leading to the loss of food security, especially on a local and regional scale and, what is rarely mentioned, has undermined the cultural identity of agriculture [9]. As a consequence, it increases the ecological footprint [10] and decreases the quality of life [11].

The decline in taking full advantage of the potential ingrained in small farms due to the increasing dominance of large agricultural holdings results in a number of serious and frequently difficult-to-overcome problems. They affect not only farmers or consumers, but also have a negative impact on the natural environment (Table 1).

Table 1. Major problems arising from the industrialization and transformation of food markets.

\begin{tabular}{|c|c|}
\hline Area & Problems \\
\hline Farmers & $\begin{array}{l}\text { - Lack of labor market stability during the recession period (increasing unemployment } \\
\text { in rural areas, migration of working age population to urban centers, etc.), } \\
\text { - deepening social inequalities and, as a consequence, advancing social exclusion, } \\
\text { - large fluctuations of, frequently, very low income, } \\
\text { - } \quad \text { issappearance of family farms, } \\
\text { - of small agricultural holdings (local collection centers, mills, slaughterhouses), } \\
\text { difficulties of young farmers in independent access to land, equipment, markets, and } \\
\text { financial capital. }\end{array}$ \\
\hline Consumers & $\begin{array}{l}\text { - Lower life quality of consumers as a result of eating highly processed products or of } \\
\text { - } \quad \text { exknown origin-"anonymous supplier" (diet-related diseases), } \\
\text { - } \quad \text { uncertainty about the origin of food and its impact on health. }\end{array}$ \\
\hline $\begin{array}{c}\text { Natural } \\
\text { environment }\end{array}$ & $\begin{array}{l}\text { - Excessive and often uncontrolled consumption of natural resources, } \\
\text { - external effects related to the increasing environmental pollution, } \\
\text { loss of biodiversity-natural and agricultural-caused by the development of } \\
\text { industrial monoculture crops, } \\
\text { - agricultural dependence on the increasing oil, chemical fertilizer, and pesticide usage } \\
\text { per unit of production. }\end{array}$ \\
\hline
\end{tabular}

Source: Authors' compilation based on: [12]. 
The aforementioned situation intrinsically imposes seeking new solutions to restore the relative balance of rural areas' development, particularly the ones ensuring lasting and ongoing cooperation between farmers and consumers. It requires economic strengthening of small agricultural holdings, however, not through increasing the stream of non-returnable funding of agricultural activities, but by focusing on the Community-Supported Agriculture (CSA). This concept stands for an alternative economic approach, extending far beyond the model of profit maximization alone, but also striving to strengthen local interactions between food producers and consumers [13]. It is a form of permanent connection between consumers and small food producers based on a partnership agreement, trust, and respect, as a result of which producers have a guaranteed stable income and consumers receive fresh food products [14]. As a result, a social and economic network based on reciprocity and trust is formed, which not only allows small farms to achieve a comparative advantage in the agricultural products market, but also contributes to the sustainable development of rural areas [15]. Stable agriculture can become a starting point for the development of agritourism and ecotourism, as well as for other small local enterprises, e.g., from the processing industry [16].

CSA is based on a direct partnership between the farmer and local consumers, in which both parties agree to share farm costs and products [17].

The idea of Community-Supported Agriculture illustrates five fundamental principles, the implementation of which allows the development of small, local farms and provides consumers with access to products from a well-known source of origin, offered at prices acceptable to both parties. They are as follows [12]:

- Partnership - the partnership principle is included in the agreement between consumers and farmers. The price is decided based on the explicitly estimated food production costs and takes into account both the work of farmers and the financial possibilities of consumers.

- Solidarity-the risks associated with food cultivation are borne by both parties. Consumers support farmers during periodic crop failures (they are prepared for lower-than-planned deliveries). Instead, in periods of high-yield harvest, they are rewarded with a surplus. Paying for the respective "share" in advance is an important component of this solidarity.

- Proximity—deliberate support for the local economy. Geographical proximity allows maintaining personal contacts with farmers and offers opportunities to explore the realities of food cultivation.

- Diversity-support for farms implementing a sustainable cultivation model based on crop rotation. A large variety of crops maintains soil health and ensures a balanced diet for consumers.

- The producer/consumer tandem: Is based on direct person-to-person contact and trust, free from intermediaries or hierarchy.

Community-Supported Agriculture can, therefore, represent a kind of remedy for a wide variety of problems threatening the efficient and effective functioning of small agricultural holdings. It is confirmed by the experiences of other countries (e.g., Japan, United States, France, Austria, Czech Republic, Hungary) where CSA has been functioning for years.

For example, the first documented collaboration for CSA in the United States began in 1985 in Western Massachusetts. In 1999, it was estimated that there were already 1,000 CSA farms in the US [18]. CSAs in France are called AMAP, which stands for Association pour le Maintien de l'Agriculture Paysanne (Association for Maintaining Small-Scale and Family Farming). The first AMAP was created in Aubagne (in Southern France) in April 2001, at the initiative of a couple of farmers and an Attac group. In 2011, the first CSA Farm started in Austria: The "Gärtnerhof Ochsenherz" was founded near Vienna. In 2013, in Europe, there were about 4,000 farms and 400 thousand consumers of CSA [19].

Thus, CSA plays an extremely important role for the development of agriculture and rural areas, as it opens new business opportunities, especially for small farms. In addition, it is a chance to develop alternative distribution channels for healthy, organic food.

The idea of CSA is also known in Poland. The attempts to use CSA are limited, in many cases, to transferring solutions developed in other countries, which often do not correspond with the specificity 
of Polish agriculture. Having observed the current transformations of Polish rural areas and taking into account the historical, social, and cultural premises affecting the nature and direction of agriculture development, a very important question arises: Can CSA offer an economically effective and, at the same time, socially responsible and environmentally beneficial model of agricultural activity under the Polish conditions, and will it help small agricultural holdings to survive?

The main purpose of the article is to identify the premises for using CSA as a prospective development model for small agricultural holdings in Poland. This goal defined the research scope as the core of the presented discussion. It addresses the important aspects from the perspective of the CSA model, i.e., the distance between a producer and a consumer, which determines the length and cost of the supply chain-its shortening expands the group of customers, thus allowing the producer to obtain the expected income. The second factor is the price, because the cost of purchasing food delivered directly by a farmer is higher than the prices offered by retail chains. They reflect the actual costs of food production on a smaller scale.

The article content is summed up by conclusions and recommendations formulated based on the analysis of the obtained research results.

\section{Materials and methods}

The research covered farmers running small agricultural holdings (up to 10 ha) in nine municipalities located in the Wrocław district in the Lower Silesia region in Poland. The selection of respondents, both in terms of location and size of the utilized arable area, was deliberate. Firstly, the selected farms are characterized by a favorable location in relation to the market created by the consumers living in Wrocław (the capital of Lower Silesia, 640 thousand inhabitants). Secondly, CSA works best on small farms, not exceeding 10 ha, functioning based on the work of the farmers and their families [20]. It is worth noting that after 1989, the structures (Table 2) and the profiles of small farms changed. There was a shift away from animal production in favor of crop production, in which cereal dominates. Vegetable cultivation is also less important. In this case, this results from labor intensity.

Table 2. The share of area groups of individual farms in Lower Silesia in 1996-2015.

\begin{tabular}{|c|c|c|c|c|c|c|c|c|}
\hline \multicolumn{9}{|c|}{ Individual Farms } \\
\hline & \multicolumn{4}{|c|}{ Number of Farms } & \multicolumn{4}{|c|}{ Area (ha) } \\
\hline & 1996 & 2002 & 2010 & 2015 & 1996 & 2002 & 2010 & 2015 \\
\hline $1-2$ ha & 25.0 & 30.9 & 22.5 & 18.5 & 3.1 & 4.5 & 2.8 & 2.1 \\
\hline $2-3$ ha & 12.9 & 13.6 & 13.9 & 12.1 & 2.8 & 3.4 & 2.9 & 2.1 \\
\hline $3-5$ ha & 14.1 & 13.9 & 16.0 & 16.6 & 4.9 & 5.6 & 5.2 & 4.6 \\
\hline $5-7$ ha & 10.4 & 9.1 & 10.2 & 11.0 & 5.6 & 5.6 & 5.1 & 4.6 \\
\hline $7-10$ ha & 14.0 & 10.9 & 11.3 & 12.3 & 10.6 & 9.5 & 8.0 & 7.3 \\
\hline 10-15 ha & 11.7 & 9.1 & 9.8 & 10.1 & 12.7 & 11.5 & 10.0 & 8.9 \\
\hline 15-20 ha & 4.9 & 4.2 & 4.7 & 5.4 & 7.5 & 7.4 & 6.8 & 6.7 \\
\hline 20-30 ha & 3.6 & 3.7 & 4.4 & 4.9 & 7.7 & 9.3 & 9.0 & 8.5 \\
\hline $30-50$ ha & 1.8 & 2.3 & 3.3 & 4.0 & 6.1 & 9.2 & 10.9 & 11.0 \\
\hline 50 ha and more & 1.7 & 2.2 & 3.8 & 5.1 & 38.9 & 33.9 & 39.1 & 44.2 \\
\hline Total [\%] & 100.0 & 100.0 & 100.0 & 100.0 & 100.0 & 100.0 & 100.0 & 100.0 \\
\hline
\end{tabular}

The location of the research in relation to the city of Wrocław is shown in Figure 1, and the list of completed survey questionnaires is presented in Table 3. 


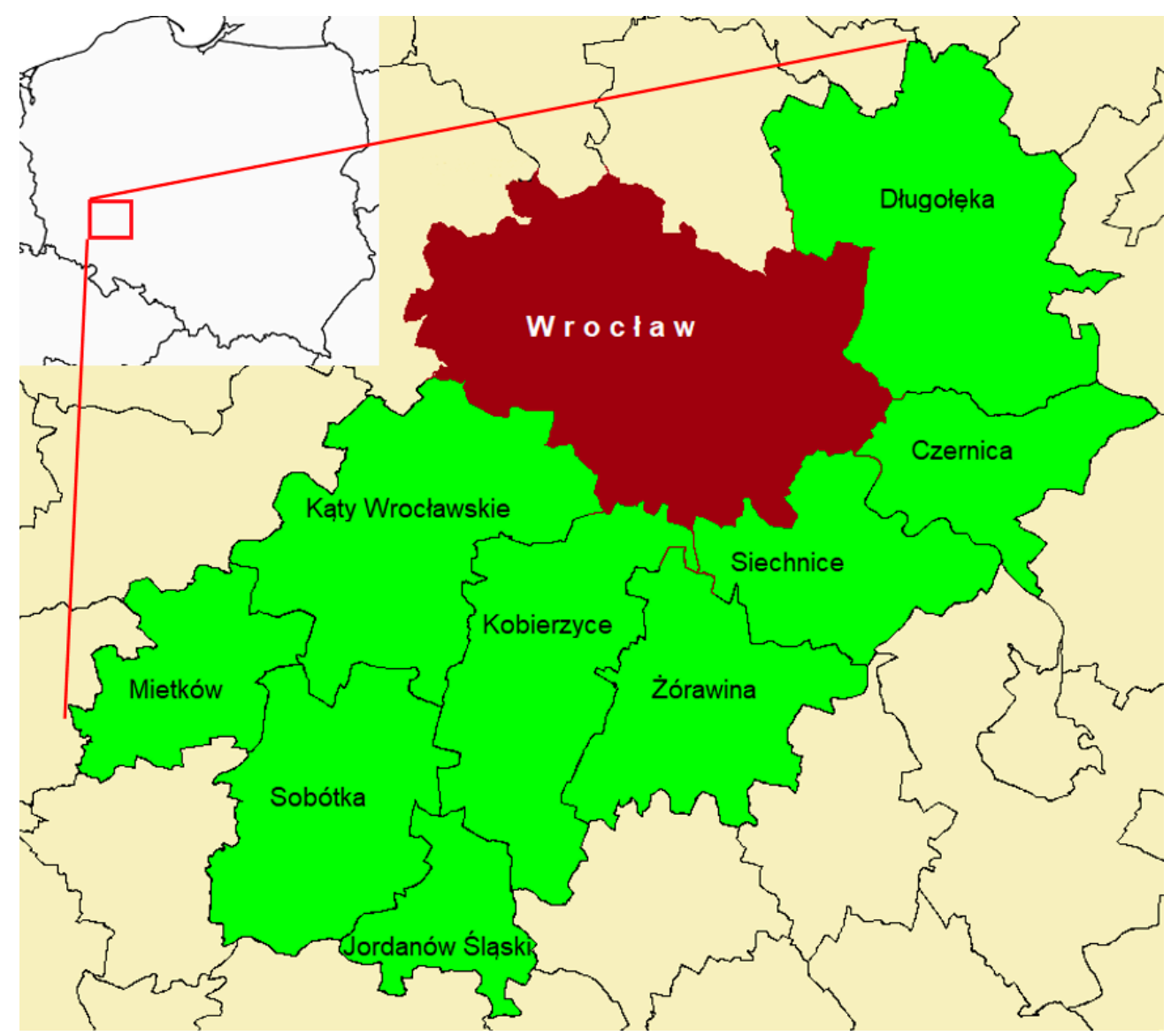

Figure 1. Research area (municipalities included in the Wrocław district). Source: Authors' compilation.

Table 3. Number of questionnaires in the municipalities covered by the research.

\begin{tabular}{cccccc}
\hline No. & $\begin{array}{c}\text { Municipality } \\
\text { Name }\end{array}$ & $\begin{array}{c}\text { Number of } \\
\text { Questionnaires in the } \\
\text { Municipality }[n=400]\end{array}$ & No. & $\begin{array}{c}\text { Municipality } \\
\text { Name }\end{array}$ & $\begin{array}{c}\text { Number of } \\
\text { Questionnaires in the } \\
\text { Municipality }[n=400]\end{array}$ \\
\hline 1. & Czernica & 50 & 6. & Mietków & 40 \\
\hline 2. & Długołęka & 50 & 7. & Siechnice & 40 \\
\hline 3. & $\begin{array}{c}\text { Jordanów } \\
\text { Slaski }\end{array}$ & 40 & 8. & Sobótka & 40 \\
\hline 4. & $\begin{array}{c}\text { Katy } \\
\text { Wrocławskie }\end{array}$ & 50 & 9. & Źórawina & 40 \\
\hline 5. & Kobierzyce & 50 & \multicolumn{5}{c}{} \\
\hline \multicolumn{5}{c}{ Source: Authors' compilation. } \\
\hline
\end{tabular}

The research was conducted in the form of survey questionnaires, containing a total of 19 questions, both open and closed. The open questions referred to the age and education of the farmer, the agricultural holding area, the type of agricultural production currently carried out, production capacity (what kinds of products could be produced within the framework of CSA), the distance over which products could be delivered to consumers, and the potential prices of products offered to consumers. Closed questions were intended to provide information about:

- Currently functioning sales models of agricultural products;

- benefits resulting from the participation in CSA;

- barriers to CSA functioning; 
- CSA support tools.

A total of 400 surveys were completed at the actual farms in the presence of trained employees (advisors) representing the Lower Silesian Agricultural Advisory Center. The number of questionnaires in the municipality was proportional to the total number of farms located in its area. Prior to completing the survey, the advisors explained the general CSA principles to all farmers involved. The participation of the Lower Silesian Agricultural Advisory Center employees in the survey also allowed the selection of these farms where agricultural activity was actually carried out.

The selected, measurable factors characterizing the respondents were subjected to statistical analysis. An important aspect of the CSA model is the manufacturer's willingness to deliver products directly to their customers. Therefore, the respondents were asked how far they are ready to deliver their goods. They are located in close proximity to Wrocław, the largest consumer market in the region. In turn, due to the diversified internal demographic structure of the selected municipalities, they are capable of functioning as a potential sales market for themselves. Location and distance to the consumer is also important from the perspective of delivery costs. The higher they are, the more unattractive CSA turns out as an alternative form of running a profitable agricultural activity.

The second important aspect of CSA is the price of products offered. The respondents were asked about the percentage increase in product prices, allowing for profitable sales under the CSA model. The quantitative measurement results of these variables, i.e., distance and sales profitability, were analyzed in terms of qualitative factors:

- Geographical location of the producer,

- CSA perception (expecting support, approaching CSA as a new sales market, profitability of using the model).

The following four research hypotheses were analyzed in this study:

- $\mathrm{H}_{1}$-geographical location does not affect the willingness to deliver goods directly from farmers to a retail customer. The willingness to deliver goods is an immanent feature of CSA. Usually, within the CSA model, it is necessary to transport agricultural products to consumers, as it is not expected for the distribution of goods to take place only by purchasing them directly from the producer. Positive verification of this hypothesis means that there is no relationship between the location of the agricultural holding and the willingness of farmers to deliver their goods to consumers; thus, this factor is a neutral one from the perspective of the farmer's potential participation in CSA. This means that, contrary to popular belief, the location of a farm does not determine the possibility of CSA development.

- $\mathrm{H}_{2}$-geographical location does not affect the need to increase retail prices of goods. The respondents' declarations are usually based on their own experience of using the intermediation system as well as the direct selling system. The results of testing this hypothesis will be compared against the respondents' declarations regarding the distribution channels they use.

- $\mathrm{H}_{3}$-the possibility of participating in CSA does not affect the willingness to deliver goods to a retail customer. The farmer's accession to CSA does not change his preconceived attitude regarding the delivery of products to consumers. The confirmation of this hypothesis (compared against the $\mathrm{H}_{1}$ analysis) shows that the awareness of transport costs is almost non-existent.

- $\mathrm{H}_{4}$-participation in CSA does not affect the need to increase the prices of goods offered within the framework of CSA. CSA usually allows selling the same products at slightly higher prices. The respondents stating that the CSA model is profitable usually declare lower price increases. The verification of this hypothesis allows assessing the respondents' awareness regarding CSA's functioning.

The standard method for detecting intergroup differences in a statistical sample is a one-way analysis of variance (ANOVA), as it is a technique that compares the means of more than two samples. ANOVA requires normal distributions and equal variances of populations. In a situation where these assumptions are not met, the Kruskal-Wallis one-way analysis of variance can be used. This 
non-parametric method is applied for testing whether samples originate from the same distribution. The Kruskal-Wallis test does not assume a normal distribution. The difference between these methods is that in the null hypothesis of Kruskal-Wallis test, the medians of all groups are equal, since ANOVA compares means. Furthermore, in the study, median values in subgroups are quoted. The distributions of variables show a very clear skewness, so the average value is not a suitable measure for the tests described here.

The assessment of distributions in all qualitative groups shows that the analyzed variables do not present normal distributions (the Shapiro-Wilk test of normality was used) or equal variances. Therefore, the verification procedure of statistical hypotheses was based on the Kruskal-Wallis test. The nonparametric test allows identification of the statistically significant differences between variable values in the analyzed subgroups.

\section{Results}

The conducted analysis shows an interesting correlation when it comes to the producers' willingness in delivering their products to a direct customer depending on the geographical location ( $\mathrm{H}_{1}$ hypothesis). The application of the Kruskal-Wallis test and the procedure of multiple comparisons allow distinguishing of two main groups of producers: Presenting a very low transport willingness (the municipalities of Czernica, Długołęka, Jordanów, Kobierzyce, Mietków, and Żórawina) and characterized by an evidently higher delivery willingness: Kąty Wrocławskie and Sobótka (transport up to $10 \mathrm{~km}$ ), as well as Siechnice (up to $20 \mathrm{~km}$ ).

Farmers' behavior closely corresponds to the current urban and demographic system of the area in question, and also to its location in relation to Wrocław. Siechnice is located approximately $15 \mathrm{~km}$ from the center of Wrocław and is the traditional area of agricultural production for the agglomeration. For years, the capital of the region has been the key sales market for the local producers.

The cities of Katy Wrocławskie, Siechnice, and Sobótka are located approximately 20-25 km from Wrocław. They are characterized by intensive settlement processes (as a result of ongoing suburbanization in the Wrocław Agglomeration); nonetheless, they still constitute isolated settlement clusters. It seems that the respondents from these areas approach the local market as the key one, although in the case of the Katy Wrocławskie municipality, the willingness to deliver products is clearly higher. The respondents delivering goods within $100 \mathrm{~km}$ (see Figure 2) were also included in the survey, which may indicate the growing role of the Wrocław market. In the case of other municipalities, the willingness to deliver products is insignificant.

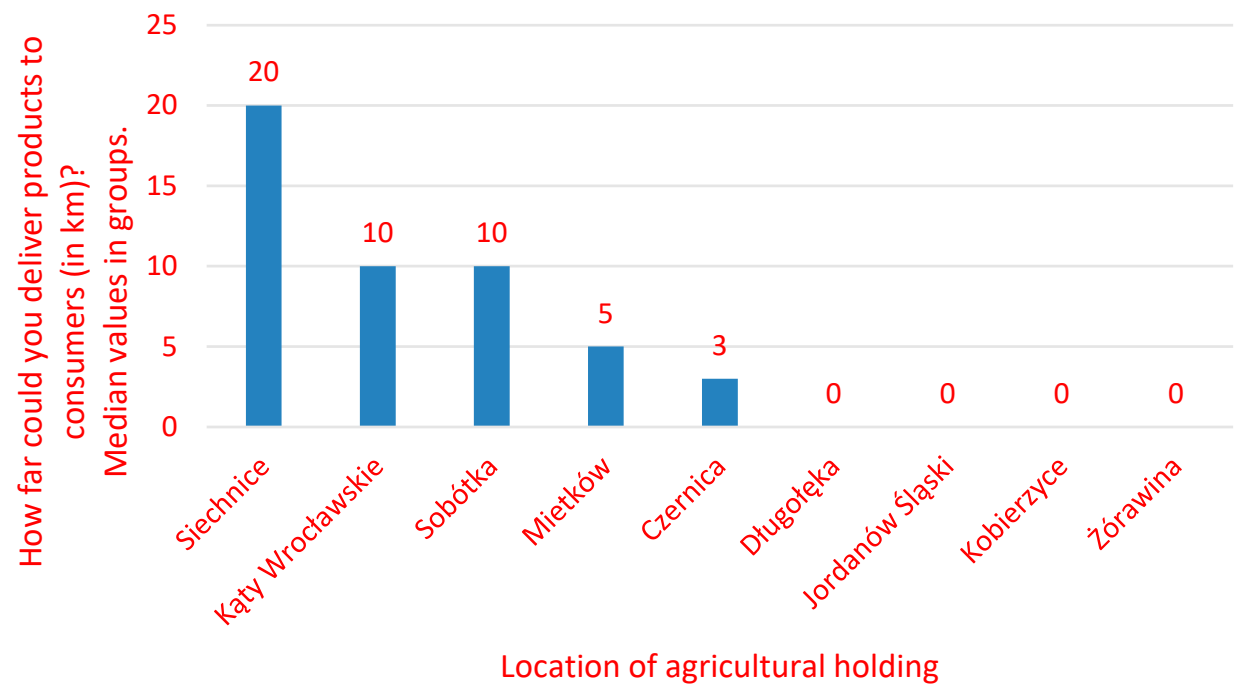

Figure 2. The distance at which the producer is willing to deliver goods to a retail consumer in geographical terms. 
Thus, the geographical factor evidently influences the willingness to deliver goods in the municipalities of Katy Wrocławskie, Siechnice, and Sobótka. In light of these findings, it seems that, as a result of this study, the $\mathrm{H}_{1}$ hypothesis was not confirmed. This shows that some CSA model mechanisms may be developed in these regions.

The answers referring to production profitability under $\mathrm{CSA}\left(\mathrm{H}_{2}\right.$ hypothesis) are interesting. The current price level of the offered products was adopted as a reference; the respondents referring to their level declared a desired price increase, compensating for their participation in the CSA.

The respondents were asked about the percentage of their products' price rise to make their production profitable in terms of its sales based on the CSA model.

The analysis of multiple comparisons allows distinguishing the groups of similar municipalities in relation to the analyzed feature (see Figure 3):

1. Katy Wrocławskie, Kobierzyce, Żurawina (typical value range within $15 \%-20 \%$ );

2. Czernica, Długołęka, Jordanów (40-50\%);

3. Siechnice, Sobótka, Mietków (over 50\%).

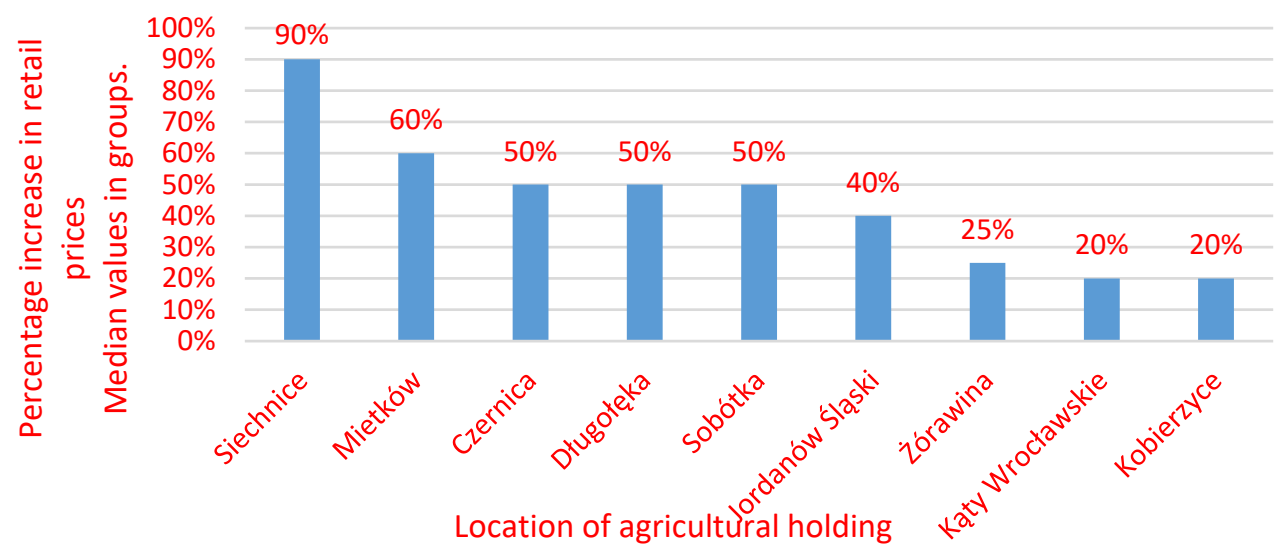

Figure 3. Percentage increase in retail prices as the compensation for Community-Supported Agriculture (CSA) participation in the geographical perspective.

The lowest level of price increase was declared by the respondents from Katy Wrocławskie, Kobierzyce, and Żurawina. The differences are significant, as confirmed by the Kruskal-Wallis test ( $p$-value $=0.00)$. The above groups of municipalities do not correspond to the respondents' declarations regarding the supply chain used. The correlation coefficients, even though statistically significant ( $p$-value $<0.05)$ are not high. CSA is basically a delivery to an individual customer. In light of the study, the level of development of the CSA model does not affect the price expectations of producers. Therefore, the situation in each municipality is probably determined by the individual characteristics, as shown in Table 4. Since the willingness to raise prices does depend on the geographical location, the $\mathrm{H}_{2}$ hypothesis is not confirmed in our study.

Many survey respondents notice that market access is the key element of the CSA model (see Figure 4). The producer's willingness to deliver goods to the retail customer is observed only in the group of respondents claiming that CSA is an opportunity for new sales markets; this difference is statistically significant (according to the Kruskal-Wallis test.) This does not confirm the assumption formulated in the form of the $\mathrm{H}_{3}$ hypothesis: If the producer recognizes the possibility of entering the new market, they are willing to transport goods over a distance of about $20 \mathrm{~km}$. No differences can be found in the case of the declared price increase which, in turn, confirms the last of the adopted hypotheses, i.e., $\mathrm{H}_{4}$. In the three analyzed groups, the differences between the values remain statistically insignificant $(p$-value $=0.12$ ). There is also no price dependence on the CSA maturity level (Table 4 ). Therefore, it should be assumed that, in all groups, the declared price increase should be about $50 \%$ to make CSA participation profitable. 
Table 4. Percentage of the respondents selling directly to a retail customer.

\begin{tabular}{ccc}
\hline Municipality Name & $\begin{array}{c}\text { Percentage of the Respondents Selling } \\
\text { Directly to a Retail Customer [\%] }\end{array}$ & $\begin{array}{c}\text { Median of the Declared } \\
\text { Price Increase [\%] }\end{array}$ \\
\hline Katy Wrocławskie & 30 & 20 \\
\hline Kobierzyce & 50 & 20 \\
\hline Żórawina & 2 & 25 \\
\hline Jordanów śląski & 15 & 40 \\
\hline Czernica & 20 & 50 \\
\hline Sobótka & 26 & 50 \\
\hline Długołęka & 36 & 50 \\
\hline Mietków & 51 & 60 \\
\hline Siechnice & 35 & 90 \\
\hline & Pearson's correlation coefficient-0.22 & \\
\hline & Spearman's rank correlation coefficient-0.26 & \\
\hline
\end{tabular}

Source: Authors' compilation based on the research results.

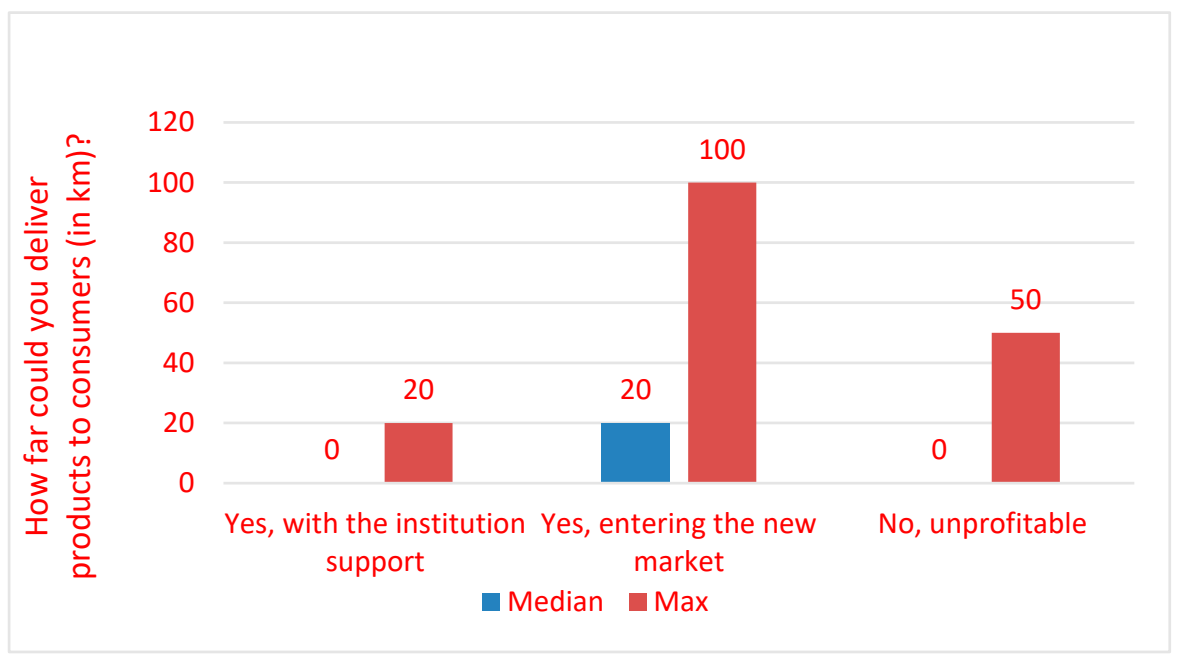

Figure 4. The declared delivery distance to a retail customer in the context of CSA perception.

In the cases of most municipalities located in the south-western vicinity of Wrocław, the respondents' willingness to deliver goods to an individual customer cannot be identified. It seems that only the farmers from Siechnica deliver goods to the largest consumer market, i.e., Wrocław. The decisive factor seems to be the transport connection with the city and its distance from the producer.

The perception of the production profitability level in the CSA model is highly diversified in geographical terms and depends on endogenous factors in the respective areas. It also seems that it does not depend on the current sales structure of agricultural products. The respondents are aware that CSA may present an opportunity to expand the sales market. In addition, they realize it will require products' delivery directly to the consumer. In the surveyed sample, the CSA perception does not affect, in any way, the valuation of production profitability.

\section{Discussion}

The concept of Community-Supported Agriculture is addressed in numerous research studies and scientific analyses. Their overview highlights that it is still perceived as an insufficiently recognized opportunity to intensify rural development processes [22]. The potential ingrained in CSA is too rarely emphasized as a real, economically and socially coherent approach to the problems of many small 
agricultural holdings [23]. This type of agriculture is a proven system of agricultural production and distribution, which aims at sharing the risk and income (agricultural produce) more fairly [24]. This fairness is manifested in, e.g., the increase in farmers' income through the elimination of further links in the supply chain. By shortening the supply chain, farmers can obtain higher prices for their products, which is consistent with their expectations presented in the outcomes of this study. At the same time, this does not have to result in price increases for consumers [12].

The foundation of CSA is a kind of partnership established between a producer and a consumer, based on mutual benefits and trust- the consumer pays in advance for regular (e.g., weekly) deliveries of parts of the goods, but also shares the production risk even in their absence [25]. It is strengthened by the consumers' active participation in field work, promoting the transition from the traditional consumer model to the prosumer one.

This makes CSA the manifestation of more advanced cooperation, requiring appropriately developed social capital as well as trust and respect between participants (consumers bear a greater risk, simultaneously offering their support to a farmer) [23]. It is distinguished from other types of direct sales by cost sharing, risk, and responsibility, as well as the occurrence of close socio-economic interactions between the producer and the consumer [26,27].

In practice, the implementation of CSA may come across various obstacles. The crucial component of the classical, "clean" CSA model is its design, i.e., trust between local producers and consumers [28]. It cannot be approached as a declarative one, though. The awareness and potential risk acceptance are important here, but so is the mutual honesty of the parties, primarily when it comes to the system of prepayments made by consumers to farmers [22].

Consumer participation in the food production process (farmer's support, e.g., during harvest) represents yet another sensitive area. As indicated by the American research example, consumers often see their intention to participate in CSA as the expression of their willingness to purchase fresh and organic local produce $[19,29-31]$. This, in turn, distorts the idea of CSA, characterized by the active participation of consumers in the process of agricultural production [14].

Therefore, the aforementioned problems open the discussion addressing the actual possibilities of CSA implementation in various countries. CSA requires a well-developed social capital, proper institutional support, and also the willingness to understand its concept by the farmers themselves, who should approach it through the prism of the entire phenomenon, rather than its selected fragments (e.g., transport costs), rejecting their concerns and stereotypical thinking about running an agricultural activity [22].

It will not be an overstatement to observe that CSA plays an important role in the development of agriculture and rural areas. However, it seems that its potential is fully activated in mature economies, which is confirmed by Western European countries, Japan, or the United States. In Poland, experiencing transformations in agriculture, CSA still faces a number of financial, organizational, and mental barriers [14]. Farmers are still dominated by skepticism and a lack of faith in the possibility of improving their competitiveness.

Nonetheless, the conducted research shows that the aforementioned negative attitudes are changing, at least partially. Not only is the awareness of the advantages associated with the participation in CSA growing among farmers, but also the potential possibility of participating in CSA does change the existing attitudes. this is proven by the fact that the $\mathrm{H}_{3}$ hypothesis has not been confirmed. The ability to operate in a new stable market means that farmers, contrary to previous attitudes, are willing to deliver goods to consumers.

Attention should also be paid to the research results referring to the geographical location's impact on farmers' willingness to deliver goods directly to consumers ( $\mathrm{H}_{1}$ hypothesis). Even though it was recognized that the geographical location affects farmers' willingness to transport goods, the results of the study allow the conclusion that, contrary to previous observations [14], the direct vicinity of Wrocław (the main market) is not the key factor for the development of CSA. 
Unfortunately, there are still barriers on the consumer side. From the consumer's perspective, the essential criterion for choosing a product is its price (the lower, the more attractive), which functions in favor of large retail chains, thus pushing small agricultural holdings to the market margin.

Beyond any doubt, the noticeable factor facilitating CSA development is the increasingly visible focus of consumers' interest in organic, traditional products of high quality and taste, produced in small batches, and of well-known origin (producer's transparency).

\section{Conclusions}

The research results, covering the municipalities of the Wrocław district and located in the direct vicinity of the city of Wrocław, allow the formulation of general conclusions regarding the development of Community-Supported Agriculture in Polish conditions:

1. Large cities constitute important sales markets for the goods produced within the framework of CSA. Their residents, representing the potential conscious consumers, are more often ready to accept higher prices in exchange for high-quality, low-processed, and organic products originating from a well-known source. In the case of the surveyed farmers, a $50 \%$ price increase for the offered products is expected, which results, e.g., from the distance to the final consumer. It should also be emphasized that higher price level acceptance will largely depend on the purchasing opportunities of the potential consumers, resulting from the economic situation of a particular city.

2. The significant factor for CSA's success in the Wrocław district seems to be the transport connection with the city and its distance from a producer. The tendency to reduce transport costs is the key premise determining farmers' willingness to deliver products to consumers. Studies have shown that the distance is not a major obstacle for those farmers who perceive CSA as an opportunity to enter new sales markets. In turn, it may result from the low awareness of the need to incur certain transport-related expenses. The costs strictly connected with delivering products to the consumer may be "lost" in other trips made by the farmer.

To sum up, CSA undeniably opens new business opportunities for Polish small agricultural holdings by creating a new market segment for agricultural products from the local (small producers) to the market (large retail chains). This is mainly due to the specificity of CSA itself, which requires committed and conscious consumers ready to pay more for the products meeting their expectations.

Author Contributions: Conceptualization, M.S., M.K.-M., M.N., M.K., M.R.; methodology, M.S., M.K.-M., M.N., M.K., M.R.; validation, M.S., M.K.-M., M.N., M.K., M.R.; resources, M.S.; data curation M.S., M.N.; writing—original draft preparation, M.S., M.K.-M., M.N., M.K., M.R.; writing—review and editing, M.S., M.K.-M., M.N., M.K., M.R.; visualization, M.N., M.K.; supervision, M.K.-M., M.K.; project administration, M.R.; funding acquisition, M.K.-M.; All authors have read and agreed to the published version of the manuscript.

Acknowledgments: The research is co-financed under the Leading Research Groups support project from the subsidy increased for the period 2020-2025 in the amount of $2 \%$ of the subsidy referred to Art. 387 (3) of the Law of 20 July 2018 on Higher Education and Science, obtained in 2019.

Conflicts of Interest: The authors declare no conflict of interest.

\section{References}

1. Kołodziejczyk, D.; Gospodarowicz, M.; Lidke, D.; Miś, T.; Raftowicz-Filipkiewicz, M.; Łabędzki, H.; Struś, M. Wieloaspektowe Ujęcie Problemu Spójności Obszarów Wiejskich na Poziomie Lokalnym i Regionalnym w Dotychczas Realizowanych i Planowanych Strategiach Rozwoju [Multi-Faceted Inclusion of the Problem of Cohesion of Rural Areas at the Local and Regional Level in the Development Strategies Implemented and Planned to Date]; Kołodziejczyk, D., Ed.; Instytut Ekonomiki Rolnictwa i Gospodarki Żywnościowej [Institute of Agricultural and Food Economics]: Warsaw, Poland, 2003.

2. Heffner, K.; Kamińska, W. (Eds.) Dychotomiczny Rozwój Obszarów Wiejskich. Czynniki Progresji, Czynniki Peryferyzacji [Dichotomous Rural Development. Progressive Factors, Peripheral Factors]; Komitet Przestrzennego Zagospodarowania Kraju Polskiej Akademii Nauk [Committee for Spatial Economy and Regional Planning, Polish Academy of Sciences]: Warsaw, Poland, 2011. 
3. Czyżewski, B.; Czyżewski, A.; Kryszak, Ł. The Market Treadmill Against Sustainable Income of European Farmers: How the CAP Has Struggled with Cochrane's Curse. Sustainability 2019, 11, 791. [CrossRef]

4. Stanny, M.; Wilkin, J. (Eds.) Ciagłość i Zmiana. Sto lat Rozwoju Polskiej Wsi; Continuity and Change. The Hundred Years of Polish Rural Development; Scholar: Warsaw, Poland, 2019; Volume 2.

5. Sorensen, T.C. Counselor: A Life at the Edge of History; Harper Publishing: New York, NY, USA, 2008.

6. Springer, S. The Discourse of Neoliberalism: An Anatomy of a Powerful Idea; Rowman \& Littlefield: London, UK, 2016.

7. Zegar, J.S. Kwestia koncentracji ziemi w polskim rolnictwie indywidualnym [The problem of land concentration in Polish individual farming]. Roczniki Nauk Rolniczych [Ann. Agric. Sci.] 2009, 96, 256-266.

8. Staniszewski, J.; Czyżewski, A. Economic factors underpinning the structural genotypes of agriculture development in the European Union after 2004. J. Agribus. Rural Dev. 2018, 50, 445-454. [CrossRef]

9. Ardakani, Z.; Bartolini, F.; Brunori, G. New Evaluation of Small Farms: Implication for an Analysis of Food Security. Agriculture 2020, 10, 74. [CrossRef]

10. Świąder, M.; Lin, D.; Szewrański, S.; Kazak, J.K.; Iha, K.; van Hoof, J.; Belčáková, I.; Altiok, S. The application of ecological footprint and biocapacity for environmental carrying capacity assessment: A new approach for European cities. Environ. Sci. Policy 2020, 105, 56-74. [CrossRef]

11. Przybyła, K.; Kulczyk-Dynowska, A.; Kachniarz, M. Quality of Life in the Regional Capitals of Poland. J. Econ. Issues 2014, 48, 181-196. [CrossRef]

12. Olszewska, J.; Trzaskowski, P. Rolnictwo Wspierane Przez Społeczność. Partnerstwo Między Rolnikami a Konsumentami [Community Supported Agriculture. Partnership between Farmers and Consumers]; Instytut Globalnej Odpowiedzialności [Institute of Global Responsibility (IGO)]: Warsaw, Poland, 2014.

13. Kraiß, K.; van Elsen, T. Landwirtschaftliche Wirtschaftsgemeinschaften (Community Supported Agriculture, CSA)_Ein Weg zur Revitalisierung des ländlichen Raumes? In Nachhaltige Entwicklung ländlicher Räume; Friedel, R., Spindler, E.A., Eds.; Verlag: Wiesbaden, Poland, 2009; pp. 183-194.

14. Struś, M. Rolnictwo wspierane przez społeczność: Przykład innowacji konstruktywnych na obszarach wiejskich [Community Supported Agriculture: An Example of Constructive Innovation in Rural Areas]. Problemy Drobnych Gospodarstw Rolnych [Probl. Small Agric. Hold.] 2018, 1, 63-71. [CrossRef]

15. Hinrichs, C. Embeddedness and local food systems: Notes on two types of direct agricultural market. J. Rural Stud. 2000, 16, 295-303. [CrossRef]

16. Atkinson, M.; Williams, J. Farmers markets: Breathing new life into old institutions. Public Manag. 1994, 76, 16-20.

17. Fieldhouse, P. Community shared agriculture. Agric. Hum. Values 1996, 13, 43-47. [CrossRef]

18. Hendrickson, J. Community Supported Agriculture: Growing Food and Community; University of Wisconsin, Centre for Integrated University of Wisconsin, Centre for Integrated Agriculture Systems: Madison, WI, USA, 1999.

19. Basford, J.; Cross, K.; Eichinger, W.; Georgakakis, A.; Iserte, M.; Kern, F.; Lešinský, D.; Pabst, S.; Parot, J.; Perényi, Z.; et al. European Handbook of Community Supported Agriculture. Sharing Experience. 2013. Available online: https:/urgenci.net/wp-content/uploads/2015/03/CSA4EUrope_Handbook.pdf (accessed on 26 March 2020).

20. Olszewska, J.A. Contextual analysis of the first year of a community supported agriculture pilot group in Poland. In Proceedings of the 14th of June 2013 during conference: The Future of Consumerism and Well-Being in a World of Ecological Constraints at Clark University in Worcester, Worcester, MA, USA, 12-14 June 2013.

21. Kutkowska, B.; Berbeka, T.; Kapała, A.; Kurtyka-Marcak, I.; Minta, S.; Raftowicz-Filipkiewicz, M.; Struś, M. Procesy Koncentracji Ziemi i Kapitatu a Zrównoważony Rozwój Obszarów Wiejskich na Dolnym Ślasku [The Processes of Concentration of Land and Capital in the Context of Sustainable Development of Rural Areas in Lower Silesia]; Raftowicz-Filipkiewicz, M., Ed.; WUELS: Wrocław, Poland, 2016; p. 29.

22. Bienkiewicz, M.; Bronkowska, M.; Kutkowska, B.; Łoźna, K.; Minta, S.; Prymon, K.; Raftowicz, M.; Struś, M.; Żurek, J. Rolnictwo Wspierane Społecznie: Badanie Szans Rozwoju Małych Gospodarstw Rolnych na Dolnym Ślasku w Aspekcie Produkcji Żywności Wysokiej Jakości, [Community Supported Agriculture - Research into the Development Opportunities of Small Farms in Lower Silesia in the Aspect of High-Quality Food Production]; Kutkowska, B., Ed.; Ad Fontes: Wrocław, Poland, 2018. 
23. Bienkiewicz, M.; Bogusiewicz, U.; Bronkowska, M.; Dmytrów, I.; Kapała, A.; Kurtyka-Marcak, I.; Kutkowska, B.; Łoźna, K.; Michniewicz, I.; Miniewska, M.; et al. Rolnictwo Wspierane Społecznie—Zmniejszenie Barier Wejścia na Rynek dla Dolnoślaskich Produktów Żywności Wysokiej Jakości, [Community Supported AgricultureReducing Market Entry Barriers for High Quality Lower Silesian Food Products]; Wydawnictwo Uniwersytetu Przyrodniczego we Wrocławiu: Wrocław, Poland, 2017.

24. Gorman, R. Human-livestock relationships and community supported agriculture (CSA) in the UK. J. Rural Stud. 2018, 61, 175-183. [CrossRef]

25. Henderson, E.; Van En, R. Sharing the Harvest: A Citizen's Guide to Community Supported Agriculture; Revised \& enlarged edition; Chelsea Green Publishing: White River Junction, VT, USA, 2007.

26. Groh, T.; Mc Fadden, S. Farms of Tomorrow Revisited. Community Supported Farms, Farm Supported Communities; Biodynamic Farming and Gardening Association: Kimberton, PA, USA, 1997.

27. Feagan, R.; Henderson, A. Devon Acres CSA: Local Struggles in a Global Food System. Agric. Hum. Values 2009, 26, 203-217. [CrossRef]

28. DeLind, L.B. Close encounters with a CSA: The reflections of a bruised and somewhat wiser anthropologist. Agric. Hum. Values 1999, 16, 3-9.

29. Ostrom, M.R. Toward a Community Supported Agriculture: A Case Study of Resistance and Change in the Modern Food System. Ph.D. Thesis, University of Wisconsin, Madison, WI, USA, 1997.

30. Conner, D.S. Community Supported Agriculture Pricing and Promotion Strategies: Lessons from Two Ithaca, NY Area Farms; Department of Applied Economics and Management College of Agriculture and Life Sciences Cornell University: Ithaca, NY, USA, 2003.

31. Lang, K.G. The Changing Face of Community-Supported Agriculture. J. Cult. Agric. 2010, 32, 17-26. [CrossRef]

(C) 2020 by the authors. Licensee MDPI, Basel, Switzerland. This article is an open access article distributed under the terms and conditions of the Creative Commons Attribution (CC BY) license (http://creativecommons.org/licenses/by/4.0/). 